\title{
UJI EFEKTIVITAS ANTIBAKTERI SEDIAAN SALEP DARI EKSTRAK DAUN KERSEN (Muntingia calabura L.) TERHADAP BAKTERI Staphylococcus aureus
}

\author{
Nur Ulina M.Br. Turnip ${ }^{1}$, Nurdianti ${ }^{2}$, Cucu Arum Dwi Cahya ${ }^{3}$ \\ Institut Kesehatan Medistra Lubuk Pakam \\ e-mail: uli.turnip98@gmail.com \\ DOI : https://doi.org/10.35451/jfm.v2i2.373
}

\begin{abstract}
:
One cause of infection is bacteria, such as Staphylococcus aureus. Kersen leaves have been widely used to treat diseases caused by bacteria. The purpose of this study: to make a formulation of kersen leaf extract ointment, and to see if the ointment has antibacterial activity against the Staphylococcus aureus bacteria. The research method carried out in this study is True experimental, including the stages: making leaf extract using maceration method using 96\% ethanol solvent, an ointment formulation made on the basis of ointment: vaselin, adeps lanae, and propylene glycol. Made in three concentrations, namely: F I with $100 \mathrm{mg}$, F II with $200 \mathrm{mg}$, and F III with $300 \mathrm{mg}$. Furthermore, the evaluation was carried out in the form of evaluation of physical stability and homogeneity, and activity test with Staphylococcus aureus bacteria using the diffusion method to use paper discs. The results showed that the ointment had good physical stability and homogeneity for 10 days of storage at room temperature. The antibacterial activity of ointment showed that the diameter of $F$ I inhibition had an average of $14.35 \mathrm{~mm}, F$ II had an average of $16.50 \mathrm{~mm}$ and F III had an average of 19.29 $\mathrm{mm}$. Based on the results obtained, it can be concluded that the preparation of kersen leaf extract ointment has a inhibitory effect on Staphylococcus aureus bacteria. The next researcher is expected to pay attention to the growing area of kersen leaves which will be used as a research sapel and to compare the testing of antibacterial activity between the leaves of kersen and the other leaves against the Staphylococcus aureus bacteria.
\end{abstract}

Keywords: Ointment, kersen leaf extract (Muntingia calabura L.), Staphylococcus aureus

\section{PENDAHULUAN}

Sejak lama manusia menggunakan tanaman untuk mencegah, mengurangi, dan menyembuhkan penyakit tertentu. World Health Organization (WHO) merekomendasikan penggunaan tanaman obat dalam pemeliharaan kesehatan masyarakat, pencegahan, pengobatan penyakit. Salah satu tanaman yang dapat dimanfaatkan adalah kersen (Muntingia calabura L.). Daun kersen berkhasiat sebagai obat batuk, peluruh dahak dan sebagai Antibakteri. Zakaria tahun 2011 melaporkan bahwa daun kersen mempunyai khasiat hipotensi, antiseptik, antioksidan, antiproliferatif dan antimikroba. Salah satu upaya yang dilakukan untuk mempermudah penggunaan daun kersen adalah dengan 
dibuat menjadi suatu sediaan topikal berupa salep (Zakaria, 2011).

Sebagian orang di dunia masih mengandalkan bahan-bahan alam untuk kesehatan termasuk di negara maju seperti Inggris, Amerika Serikat, Singapore, Jepang. Mereka yakin tanaman obat lebih aman dibanding dengan obat bahan kimia apalagi di konsumsi secara rutin. Menurut riset yang telah dilakukan dibeberapa Fakultas Khususnya di Fakultas Kedokteran Menyimpulkan Manfaat Daun Kersen (Muntingia calabura L.) sebenarnya sudah dioptimalkan dari zaman dulu untuk menurunkan gula darah yang tinggi. Dan ternyata pengobatan tak selalu dengan obat-obatan yang mengeluarkan biaya banyak (Ibad, 2015).

Daerah Jawa Barat, Jawa Tengah, Jawa Timur juga banyak masyarakat yang menggunakan tanaman kersen (Muntingia calabura L.) sebagai antiseptik untuk ternak. Masyarakat Jawa menggunakan daun kersen sebagai antiseptik karena masyarakat Jawa percaya bahwa kandunga didalam daun kersen dapat digunakan sebagai antibakteri yang dapat membunuh atau menghambat pertumbuhan bakteri yang menyerang ternak (Prawira,2013).

Salep merupakan salah satu bentuk sediaan farmasi yang di gunakan pada kulit sehat, sakit atau terluka dimaksudkan untuk efek topikal. Salep digunakan untuk mengobati penyakit kulit yang akut atau kronis, sehingga diharapkan adanya penetrasi ke dalam lapisan kulit agar dapat memberikan efek yang di inginkan. Komposisi salep terdiri dari bahan obat atau zat aktif dan basis salep atau biasa di kenal dengan sebutan zat pembawa bahan aktif (Ansel, 1989).

\section{Staphylococcus}

aureus

merupakan bakteri gram positif yang berbentuk bulat dan merupakan bakteri patogen utama pada manusia, Staphylococcus aureus juga dapat menyebabkan bermacam-macam infeksi seperti jerawat dan bisul pada manusia dan hewan, hanya saja bakteri Staphylococcus aureus ini bisa menyebabkan infeksi serius dan fatal dan biasanya paling sering mengkontaminasi luka pasien pasca bedah (Nasution, 2014).

Ekstrak etanol daun kersen (Muntingia calabura L.) pada penelitian inidi formulasikan dalam sediaan salep, bahan dasar salep yang digunakan yaitu dasar salep yang sukar tercuci dengan air, dimana hanya sejumlah komponen air atau senyawa polar yang dapat dicampur kedalamnya sehingga memungkinkan untuk memperpanjang kontak antara ekstrak dengan kulit, sukar tercuci dan tidak mengering (Lubis, 2014). Dalam proses ekstraksi ini digunakan pelarut etanol 96\%, karena pelarut etanol $96 \%$ memiliki kemampuan yang baik untuk menarik senyawa metabolit sekunder yang bersifat polar dan non polar pada daun Kersen.

Menurut jurnal Virsa mengatakan ekstrak etanol daun kersen (Muntingia calabura L.) dapat menghambat pertumbuhan bakteri yang ada pada jerawat. Dengan adanya pengecekan terhadap bakteri yang ada pada jerawat, dapat dilakukannya kembali penelitian terhadap bakteri-bakteri yang lainnya.

Berdasarkan latar belakang penelitian di atas maka penulis melakukan penelitian untuk melihat bagaimana aktivitas antibakteri ekstrak etanol daun kersen yang di formulasikan dalam sediaan salep terhadap bakteri Staphylococcus aureus.

\section{METODE}

\section{Bahan}

Sampel yang digunakan yaitu daun kersen (Muntingia calabura L.) diambil dari DesaSisumut, Kecamatan Kota Pinang, Kabupaten Labuhanbatu Selatan, Provinsi Sumatera Utara,adeps 
lanae, biakan murni staphylococcus aureus, nutrient agar (NA), nutrient broth (NB), propilen glikol dan vaselin. Bahan kimia yang digunakan adalah alfanaftol, asam klorida pekat, asam asetat anhidrad, asam asetat glasial, asam nitrat pekat, asam sulfat pekat, benzen, besi (III) klorida, bismut (III) nitrat, etil asetat, $n$-heksan, iodium, isopropanol, kalium iodida, kloralhidrat, kloroform, metanol, natrium hidroksida, natruim klorida, natrium sulfat anhidrat, raksa (II) klorida, serbuk magnesium dan timbal (II) asetat, etanol 96\%, dimetlsulfoksida (DMSO), aquadest.

\section{Alat}

Aluminium foil, autoklaf, batang pengaduk, blender, beaker glass, cawan petri, cawan porselin, deck glass, erlenmeyer, gelas ukur, inkubator, jangka sorong, jarum ose, objek glass, kain kasa, kapas, kertas cakram, kertas label, kertas perkamen, kulkas, laminal air flow, lampu bunsen, lumpang dan stamper, neraca analitik, oven, pinset, pipet mikro, rak tabung, rotary evaporator, spatula, dan tabung reaksi.

\section{Pengolahan Sampel}

Sampel yang digunakan adalah daun kersen (Muntingia calabura L.). Daun kersen sebanyak $2 \mathrm{~kg}$, dicuci dengan air mengalir, kemudian di tiriskan, setelah itu beratnya ditimbang sebagai berat basah. Kemudian dikeringkan dilemari pengering pada suhu \pm $40^{\circ} \mathrm{C}$. Sampel yang telah kering biasanya ditentukan dari kerapuhan dan mudah patahnya bahan tumbuhan yang dikeringkan. Beratnya kemudian ditimbang sebagai berat kering, lalu dihaluskan dengan menggunakan blender, diayak dengan ayakan, sehingga didapat serbuk simplisia. Serbuk simplisia dimasukkan kedalam wadah kaca yang berwarna gelap yang tertutup rapat dan disimpan pada suhu kamar.

\section{Pembuatan Ekstrak}

Pembuatan ekstrak dilakukan
dengan cara maserasi dengan menggunakan palarut etanol $96 \%$. Cara kerja: Sebanyak 500 gram serbuk simplisia dimasukan kedalam wadah maserasi, lalu dilarutkan dalam 75 bagian etanol, sebanyak 3,750 $\mathrm{ml}$, ditutup, dibiarkan selama 5 hari terlindung dari cahaya sambil sesekali diaduk. Setelah 5 hari sampel disaring, setelah itu ampas yang disaring dimaserasi kembali dengan pelarut 25 bagian etanol sebanyak $1,250 \mathrm{ml}$ hingga diperoleh seluruh pelarut 5 liter. Kemudian didiamkan selama 2 hari selanjutnya disaring.Maserat yang diperoleh diuapkan menggunakan rotary evaporator pada temperatur $\pm 400 \mathrm{C}$ sampai diperoleh ekstrak kental (Depkes RI, 1979).

\section{Pembuatan Formulasi Sediaan Salep}

Pembuatan Formulasi Sediaan Salep Formula salep diambil dari (Ditjen POM, 1978)

Basis salep:

Propilen glikol $1 \mathrm{gram}$

Adeps lanae $1 \mathrm{gram}$

Vaselin album ad $10 \mathrm{gram}$

Sediaan salep dibuat kedalam 3 konsentrasi dan blanko dimana masingmasing sediaan memiliki bobot $10 \mathrm{gram}$. Blanko : Formulasi tanpa mengandung ekstrak etanol daun kersen.

a. Formulasi I: Formulasi mengandung $100 \mathrm{mg}$ ekstrak etanol daun kersen.

b. Formulasi II: Formulasi mengandung 200mg ekstrak etanol daun kersen.

c. Formulasi III: Formulasi mengandung $300 \mathrm{mg}$ ekstrak etanol daun kersen.

\section{Evaluasi Sediaan Salep}

Evaluasi formula meliputi evaluasi fisik dan biologi. Evaluasi fisik meliputi 
pemeriksaan stabilitas sediaan, pemeriksaan homogenitas.

\section{Pembuatan Inokulum Bakteri} Staphylococcus aureus

Dari stok kultur bakteri Staphylococcus aureus yang telah tumbuh diambil dengan menggunakan jarum osesteril, kemudian disuspensikan kedalam $10 \mathrm{ml}$ media Nutrient Broth. Diukur kekeruhan larutan (Ditjen POM, 1995).

Zona bening disekitar kertas yang telah direndam selama 1 menit dengan ekstrak daun kersen dengan menggunakan jangka sorong.

\section{Pembuatan Larutan Uji Sediaan Salep}

a. Formula I: Ditimbang salep ekstrak etanol daun kersen $100 \mathrm{mg}$ sebanyak 1 gram lalu dilarutkan dalam $1 \mathrm{ml}$ pelarut DMSO.

b. Formula II: Ditimbang salep ekstrak etanol daun kersen $200 \mathrm{mg}$ sebanyak 1 gram lalu dilarutkan dalam $1 \mathrm{ml}$ pelarut DMSO.

c. Formula III: Ditimbang salep ekstrak etanol daun kersen 300mg sebanyak 1 gram lalu dilarutkan dalam $1 \mathrm{ml}$ pelarut DMSO.

d. Blanko: pelarut DMSO.

\section{Uji Aktivitas Antibakteri Sediaan Salep Ekstrak Etanol Daun Kersen Terhadap Bakteri Staphylococcus aureus}

Medium NA dituang kecawan petri sebanyak $10 \mathrm{ml}$, masing-masing bakteri Staphylococcus aureus sebagai biakan uji, dipipet dari medium larutan $\mathrm{NaCl} 0,9 \%$ ke 4 cawan petri steril masing-masing sebanyak $0,1 \mathrm{ml}$, cawan petri kemudian digoyang secara perlahan-lahan untuk menyebarkan biakan bakteri secara merata dan didiamkan hingga medium memadat.Masing-masing dari cakram kertas steril dipindahkan secara aseptik menggunakan pinset steril ke konsentrasi salep ekstrak daun kersen yakni: $100 \mathrm{mg}$, $200 \mathrm{mg}$, 300mg dan blanko, direndam \pm 1 menit. Kertas cakram yang telah direndan dengan salep ekstrak etanol daun kersen dalam beberapakonsentrasi dan blanko, dipindahkan dengan pinset steril ke medium NA yang sudah berisi bakteri Staphylococcus aureus secara aseptik, kemudiaan diinkubasi selama 1 X 24 jam dengan suhu $37^{\circ} \mathrm{C}$. Setelah diinkubasi, diamati zona bening yang terdapat disekitar kertas cakram dan diukur diameternya menggunakan jangka sorong. Dilakukan tiga kali pengulangan.

\section{HASIL DAN PEMBAHASAN}

Hasil daya hambat yang diperoleh dari sediaan salep ekstrak daun kersen mengalami peningkatan yaitu pada Formulasi I yang mengandung $100 \mathrm{mg}$ ekstrak memiliki rata-rata zona hambat $14.35 \mathrm{~mm}$, Formulasi II yang mengandung $200 \mathrm{mg}$ ekstrak memiliki rata-rata zona hambat $16.50 \mathrm{~mm}$, Formulasi III yang mengandung $300 \mathrm{mg}$ ekstrak memiliki rata-rata zona hambat $19.29 \mathrm{~mm}$ dan Blanko tidak menunjukkan adanya daya hambat terhadap bakteri. Hasil diameter Hambat sediaan salep ekstrak daun kersen terhadap bakteri Staphylococcus aureus dapat dilihat pada tabel 1.

Tabel 1. Diameter Hambat Sediaan Salep Ekstrak Daun Kersen terhadap Bakteri Staphylococcus aureus

\begin{tabular}{|l|c|c|c|c|}
\hline \multirow{2}{*}{ Sediaan } & \multicolumn{3}{|c|}{$\begin{array}{c}\text { Diameter Daerah } \\
\text { Hambat }\end{array}$} & $\begin{array}{c}\text { Rata-rata } \\
\text { diameter daerah } \\
\text { diambat }\end{array}$ \\
\cline { 2 - 4 } & I & II & III & hambar \\
\hline Formulasi I & 14.35 & 14.36 & 14.35 & 14.35 \\
\hline
\end{tabular}




\begin{tabular}{|l|l|l|l|l|}
\hline Formulasi II & 16.30 & 16.51 & 16.50 & 16.50 \\
\hline Formulasi III & 19.23 & 19.30 & 19.29 & 19.29 \\
\hline Blanko & 12.00 & 12.00 & 12.00 & 12.00 \\
\hline
\end{tabular}

Keterangan:

Formulasi I : mengandung 100 mg ekstrak daun kersen

Formulasi II : mengandung 200 mg ekstrak daun kersen

Formulasi III: F 300 mg ekstrak daun kersen

Menurut Ditjen POM (1995), suatu sediaan dikatakan memiliki daya hambat bakteri jika memenuhi persyaratan dengan diameter daerah hambat bakteri kurang 14 sampai 16 $\mathrm{mm}$. Oleh karena itu ketiga formulasi sediaan salep ekstrak daun kersen dari hasil penelitian ini sudah memenuhi persyaratan sebagai sediaan antibakteri. Hal ini disebabkan oleh beberapa faktor yang mungkin terjadi seperti banyaknya larutan uji yang terserap kedalam kertas cakram, dan pengaruh dari senyawa kimia dari ekstrak daun kersen.

\section{SIMPULAN DAN SARAN}

\section{Simpulan}

Salep ekstrak daun kersen memiliki daya antibakteri terhadap bakteri Staphylococcus aureus yang dibuktikan adanya diameter daya hambat. Salep ekstrak daun kersen efektif terhadap bakteri Staphylococcus aureus.

\section{Saran}

Untuk peneliti selanjutnya disarankan untuk lebih memperhatikan daerah tumbuh dari daun kersen dan melakukan perbandingan pengujian aktivitas antibakteri antara daun kersen dengan daun yang lainnya terhadap bakteri Staphylococcus aureus

\section{DAFTAR PUSTAKA}

\section{Buku:}

Anief, M. (1986). Ilmu Farmasi. Jakarta: Ghalia Indonesia. Halaman 61

Ansel,H.C. (1989). Pengantar Bentuk Sediaan Farmasi. Edisi Keempat. Jakarta: Penerbit UI Press.

\section{Jurnal:}

Ibad, M.R, et al. (2015). Pengaruh Ekstrak Daun Kersen (Muntingia calabura L) Terhadap Derajat Eritema Proses Inflamasi Marmut (Cavia Porsellus) Dengan Luka Bakar Derajat II Dangkal. Volume I Malang. Universitas Brawijaya. Hal: 1.

Lubis,Muhiddin. (2014). Formulasi Salep Ekstrak Etanol Cacing Tanah Dan Uji Aktifitasnya Terhadap Bakteri Staphylococcus aureus. Sumatera Utara Jurusan Farmasi Universitas Sumatera Utara.

Nasution,M. (2014). Pengantar Mikrobiologi. Medan: USU Press. Hal.24-25, 28 75-76.

Prawira. (2013). Uji Kandungan Daun Kersen (Muntingia calabura L.) Sebagai Antibakteri Pada Hewan Ternak. Jurnal Penelitian. Universitas Sebelas Maret. Surakarta. Hal: 1.

Zakaria, Z,A, et al. (2011). In Vitro Antipoliferative And 
Antioxidant Activites of The Ekstracts of Muntingia Calabura Leaves. The America Journal Of Chinese Medicine, 39 (1): 183-200.

\section{Peraturan dan Undang-undang:}

Depkes RI. (1979). MateriaMedika Indonesia.Jilid III. Jakarta: DepartemenKesehatan RI.
Ditjen POM. (1978). Formularium Nasional.Edisi Kedua. Jakarta: DepartemenKesehatanRI. Halaman66.

Ditjen POM. (1995). Farmakope Indonesia.Edisi IV. Jakarta: DepartemenKesehatan RI. Halaman 855, 896, 898, 1035. Halaman 33, 167-170. 